\title{
ANALISIS PEDAGOGI CONTENT KNOWLEDGE DI DALAM KONTEKS PENDIDIKAN KARAKTER: SEBUAH STUDY META- SYNTHESIS
}

\author{
Zaenal Abidin ${ }^{1)}$ \\ ${ }^{1}$ Pendidikan Biologi, FKIP, Universitas Kuningan \\ Email :zaenal.abidin@uniku.ac.id
}

APA Citation: Abidin, Z. (2019). Analisis Pedagogi Content Knowledge Di Dalam Konteks Pendidikan Karakter: Sebuah Study Meta-Synthesis. Quagga: Jurnal Pendidikan dan Biologi, 11(1), 34-42. doi: 10.25134/quagga.v11i1.1512.

Received: 28-11-2018

Accepted: 25-01-2019

Published: 28-01-2019

\begin{abstract}
Abstrak: Sebagai sebuah studi meta-synthesis, studi ini mencoba untuk menganalisis PCK yang berkaitan dengan pendidikan karakter. Studi penelitian yang digunakan adalah desains studi kualitatif. Review literature menggunakan data base ERIC dengan menggunakan kata kunci pedagogical content knowledge.pdf dan google dengan kata kunci pedagogical content knowledge.pdf dan character education.pdf. Jurnal yang diperoleh disortir dan diambil jurnal PCK yang berkaitan dengan sains dan pendidikan karakter atau hasil belajar.Dari 200 jurnal PCK sains, akhirnya diambil 15 jurnal yang berkaitan langsung maupun tidak langsung dengan pendidikan karakter untuk dianalisis lebih lanjut.Penelitian umumnya menggunakan guru in-service sebagai partisipan.Instrument yang digunakan umumnya wawancara.Desain penelitian yang digunakan umumnya kualitatif.Penelitian PCK yang menyangkut pendidikan karakter secara khusus hampir tidak ditemukan.Namun demikian ada beberapa penelitian PCK yang mengaitkan dengan hasil belajar berupa karakter tertentu.Karakter yang ditelaah diantaranya adalah karakter kreatif dan rasa ingin tahu (satu jurnal); karakter confidence \& meaning fullness; affective, perceived control, cognitive belief teacher, efficacy state; sikap guru; social responsibility \& self actualization; solving skill.Temuan menunjukkan PCK guru menjadi syarat perlu, namun tidak menjadi syarat cukup untuk meningkatkan karakter peserta didik, dan PCK dapat mempengaruhi tindakan siswa dalam hal ini minat/motivasi dan prestasi.
\end{abstract}

Kata kunci :Pedagogi Content Knowledge (PCK), Pendidikan Karakter, Meta-Synthesis

Abstract: As a meta-synthesis study, this study attempts to analyze PCK related to character education. The research study used is a qualitative study design. Review literature using the ERIC data base by using pedagogical content knowledge.pdf and google keywords with the keywords pedagogical content knowledge.pdf and character education.pdf. The obtained journals are sorted and taken by PCK journals related to science and character education or learning outcomes. Of the 200 PCK science journals, 15 journals were finally taken that were directly or indirectly related to character education for further analysis. Research generally uses inservice teachers as participants. The instruments used are generally interviews. The research design used is generally qualitative. PCK research concerning character education in particular is hardly found. However, there are several PCK studies that relate to learning outcomes in the form of certain characters. The characters studied include creative character and curiosity (one journal); confidence \& meaning fullness character; affective, perceived control, cognitive belief teacher, efficacy state; teacher's attitude; social responsibility \& self actualization; solving skill. The findings indicate that teacher PCK is a necessary condition, but it is not a sufficient requirement to improve the character of students, and PCK can affect students' actions in this case their interests / motivations and achievements.

Keywords: Content Knowledge Pedagogy (PCK), Character Education, Meta-Synthesis

\section{PENDAhuluan}

Pengembangan professional guru sains menurut Lee S. Shulman. (1986) dan NSTA \& AETS (1998) dapat dilakukan diantaranya melalui pengembangan kompetensi pengetahuan (knowledge) yang meliputi subject matter content knowledge (CK), pedagogica knowledge (PK) atau curricular knowledge, dan pedagogical content knowledge (PCK).
Demikian pula dengan hasil kesepakatan pertemuan antara The Association for Science Education, Institute of Physics, Royal Society of Biology, Royal Society of Chemistry and the Royal Society diantaranya adalah bahwa sangat penting memasukkan subyek spesifik di dalam pengembangan professional seorang guru, diantaranya PCK (Blömeke, S. \& Delaney, S., 2012). Sedangkan menurut Thilo Kleickmann 
Quagga: Jurnal Pendidikan dan Biologi

Volume 11, Nomor 1, Januari 2019

et.all (2013) yang dikutip oleh OECD bahwa kompetensi yang dibutuhkan di dalam pengembangan professional guru terdiri dari dua komponen utama yaitu kemampuan kognitif (cognitive abilitis) dan affective-motivational. Salah satu komponen pengembangan kemampuan kognitif adalah PCK. Kompetensi content knowledge (CK) seorang guru dan dosen meliputi penguasaan konsep-konsep disiplin ilmu, hubungan antar konsep dan perkembangan konsep. Kompetensi pedagogical knowledge (PK) meliputi penguasaan teori perkembangan berpikir, teori belajar, model-model pembelajaran, assesmen hasil belajar dan manajemen kelas. Kompetensi pedagogical content knowledge (PCK) meliputi penguasaan kurikulum suatu disiplin ilmu (curricular knowledge), mengenali gaya belajar dan kesulitan belajar, mengasses konsepsi siswa (prekonsepsi dan miskonsepsi), memiliki strategi pembelajaran sesuai topik dan kondisi siswa, dan mengasses hasil belajar siswa.

Menurut Jan H. van Driel, et.all (1998) dan Raimundo Olfos, et.all .(2014) CK merupakan prasyarat bagi pembangunan PCK. PCK dan CK adalah komponen kunci dari kompetensi guru yang mempengaruhi kemajuan siswa.CK dan PCK mempengaruhi belajar siswa.Walaupun CK dan PCK memiliki korelasi yang tinggi, tetapi CK memiliki daya prediksi yang lebih rendah untuk kemajuan siswa dari pada PCK. Selanjutnya, PCK mempunyai dampak yang menentukan pada aspek-aspek kunci dari kualitas pembelajaran dan kemampuan PCK guru berkorelasi positif dengan efektivitas pembelajaran dan hasil belajar siswa (Heater C Hill., 2008 : Kim Lange,et.all., 2012 : Mustafa ÖZDEN., 2008). CK yang kuat belum tentu mengarah pada pengembangan PCK (Thilo et al, 2013:91). Ck berpengaruh positif secara signifikans terhadap PCK guru dan mempengaruhi praktek mengajar yang efektif (Federick J. Ngo., 2013). OECD menemukan PK sebagai prediktor kuat prestasi matematika siswa dibandingkan dengan variabel siswa, sekolah, dan latar belakang lainnya, namun pengaruhnya terkonsentrasi di antara siswa berprestasi tinggi. Claire H. Majori \& Betsy Palmer (2006) telah merangkum berdasarkan hasil riset Hill, Rowan and Ball (2005), Baumert et al. (2010), and Voss, Kunter and Baumert (2011) tentang pengaruh pengetahuan guru terhadap outcome pembelajaran siswa yang berfokus pada pengetahuan konten (content knowledge) dan
p-ISSN 1907-3089, e-ISSN 2651-5869

https://journal.uniku.ac.id/index.php/quagga

PCK. Hasilnya bahwa PCK lebih berpengaruh terhadap outcome pembelajaran siswa dibanding CK dan hanya PCK yang memiliki dampak/pengaruh terhadap pembelajaran.

PCK mentransformasikan subject matter knowledge sehingga dapat digunakan secara efektif dan fleksibel di dalam proses komunikasi antara guru dan siswa selama pembelajaran di kelas (Raimundo Olfos, et.all., 2014). Transformasi semakin kuat bila guru mengkomunikasikan pengetahuan barunya [13]. Berdasarkan penelitian Shulman (1986:7) dan koleganya yang berkolaborasi dalam Knowledge Growth in Teaching (KGT) project, PCK sebagai pengetahuan disusun secara bersama-sama oleh subject matter knowledge (SMK), pedagogical knowledge (PK), dan knowledge of context $(\mathrm{KC})$ (Magnusson, Set.all., 1999). Sedang menurut Lederman (Eds.) di dalam PCK terdapat tiga konstruk internal yang saling berinteraksi, yaitu content knowledge (PCK-CK) atau SMK, pedagogical knowledge (PCK-PK) dan contextual knowledge (PCK-CxK), SMK atau PCK-CK mencakup pengetahuan substantif mencakup organisasi konten ilmu dan pengetahuan sintaktikal mencakup merumuskan dan cara validasi pengetahuan. PCK-PK mencakup pengelolaan kelas, prinsip-prinsip pengajaran (instruksional), pembelajar dan belajar, dan tujuan pendidikan. PCK-CxK mencakup masyarakat, siswa, sekolah dan daerah.

PCK untuk guru sains berdasarkan hasil kerja Grossman (1990) dan Tamir (1988) \{dalam Lederman (Eds.)\} terdiri dari lima komponen yaitu (1) orientasi terhadap pengajaran sains; (2) pengetahuan dan kepercayaan tentang kurikulum sains; (3) pengetahuan dan kepercayaan tentang pemahaman siswa pada topic spesifik sains; (4) pengetahuan dan kepercayaan tentang assesmenr di dalam sains; dan (5) pengetahuan dan kepercayaan tentang strategis instruksional untuk pengajaran sains. Orientasi terhadap pengajaran sains saling berinteraksi pengaruh dengan keempat komponen lainnya.Pengetahuan tentang kurikulum termasuk di dalamnya kurikulum sains yang spesisifik dan tujuan serta sasaran sain. Pengetahuan assesmen sain mencakup dimensi pembelajaran sains yang diasses dan metode asessmen terhadap pembelajaran sains. Pengetahuan strategi intruksional mencakup strategi spesifik sains (untuk berbagai topik) dan strategi untuk topik spesifik sains. Pengetahuan pemahaman siswa terhadap sain mencakup 
Quagga: Jurnal Pendidikan dan Biologi

Volume 11, Nomor 1, Januari 2019

kebutuhan untuk pembelajaran dan area yang dianggap sulit oleh siswa.

Menurut Morine-dershimer, G., \& Kent, t. (1999) berdasarkan penjelasan Shulman paling tidak terdapat tiga hal yang harus menjadi catatan penting, yaitu pertama, pengetahuan dasar dan tujuan pendidikan tidak dapat dipisahkan dari prosedur evaluasi dan assesmen; kedua, pengetahuan kurikulum dipengaruhi oleh pengetahuan konten dan pengetahuan tujuan/prosedur assesmen, sementara itu pengetahuan pedagogi dipengaruhi oleh pengetahuan pembelajar/ pembelajaran dan pengetahuan tujuan/prosedur assesmen; ketiga, pengetahuan konteks umum pendidikan sebagai kategori menggambarkan sub kategori dari pengetahuan konteks spesifik, tetapi masingmasing kategori berkontribusi terhadap PCK. Hasil penelitian Abd-el-Khalick, F. (2006) menunjukkan bahwa PCK guru ditentukan oleh latar belakang pendidikan guru, latar belakang pengalaman bekerja sebelum menjadi guru, dan masa kerja menjadi guru.Penelitian dilakukan di salah satu SMA di the Northwestern United States. Adapun hasil penelitian Mulholland, J., \& Wallace, J. (2005) tentang perjalanan karir seorang guru sekolah menengah atas di Australia dari mulai menjadi mahasiswa calon guru, guru pemula sampai menjadi guru berpengalaman yang diamati selama 10 tahun, ternyata perjalanan karir tersebut sangat mempengaruhi PCK seseorang. Apabila PCK dimetaforakan sebagai pohon, PCK dari waktu ke waktu akan terus tumbuh dan berkembang sehat seperti pohon yang rimbun dengan percabangan dan ranting yang banyak.

Penelitian tentang PCK umumnya dilakukan pada calon guru sebagai sudi kasus. Guru preservice dijadikan studi kasus PCK karena guru pre-service memiliki $\mathrm{PCK}, \mathrm{CK}$ dan $\mathrm{PK}$ yang minim atau belum berkembang (Sevgi AYDIN \& Yezdan BOZ, 2012). Hasil penelitian Schmelzing. S, et.all (2013) menunjukkan bahwa PCK guru in-service memiliki nilai lebih tinggi dari pada guru pre-service. Penelitian PCK juga umumnya menyangkut komponen PCK dan bukan sccara keseluruhan (Sevgi AYDIN \& Yezdan BOZ, 2012). Seperti yang dilakukan oleh Dilek Karışan (2013) yang menggunakan empat komponen PCK menurut Magnusson, S, et.all (1999) untuk mengetahui PCK guru dengan tingkat keberhasilan akademik yang berbeda. Sedangkan Betu"1 Demirdo"g־en (2016) meneliti bagaimana pengaruh orientasi guru terhadap
p-ISSN 1907-3089, e-ISSN 2651-5869

https://journal.uniku.ac.id/index.php/quagga

PCK guru dan sebaliknya. Disisi lain Loughran, John.,et.all (2012) yang telah menawarkan dua instrument untuk mengartikulasikan, menggambarkan, dan menangkap pengetahuan PCK guru sains yaitu CoRe (Content Representation) dan PaP-eRs (Professionalexperince Repertoires). CoRe berisi uraian konsep-konsep atau materi yang dipentingkan dalam mengajarkan suatu topik tertentu.Sedangkan PaP-eRs berisi catatancatatan pemikiran dan pertimbangan guru untuk mengajarkan topik tertentu. CoRe dan PaP-eRs telah banyak dijadikan sebagai acuan untuk penelitian PCK CoRes asTools for Promoting Pedagogical Content Knowledge of Novice Science Teachers (Anne Hume, 2010), Exploring the Development of Pre-Service Science Elementary Teachers' Pedagogical Content Knowledge (Pernilla Nilsson \& John Loughran, 2012), Science Teachers' Views on CoRes and PaP-eRs as a Framework for Articulating and Developing Pedagogical Content Knowledge (Adam Bertram \& John Loughran, 2012), Using CoRes to Develop the Pedagogical Content Knowledge (PCK) of Early Career Science and Technology Teachers (John Williams \& John Lockley, 2012), Canonical pedagogical content knowledge by CoRes for teaching acid-base chemistry at high school (Clara Alvarado, et.all 2015), Pedagogical Content Knowledge (PCK) Guru dalam Pembelajaran Biologi SMA di Kota Cimahi. Prosiding Seminar Nasional Sains dan Pendidikan Sains(Yeni Rahmadhani, Adi Rahmat, \& Widi Purwianingsih, 2016), Preservice Science Teachers' Orientations Towards Teaching Science to Middle Schoolers (Nurcan CANSIZ \& Mustafa CANSIZ, 2016), Profil Kemampuan Pedagogical Content Knowledge (PCK) Calon Guru Biologi (Sri Sukaesih, Saiful Ridlo, \& Sigit Saptono, 2017).

Penelitian-penelitian PCK lainnya berkisar tentang bagaimana menumbuh-kembangkan PCK guru baik pre-service maupun in-service. Ada yang melalui instruksi berbasis inquiry (Prasart Nuangchalerm, 2012); Byoung S. Kim, et.all; melalui refleksi di dalam tindakan (Soonhye Park \& J. Steve Oliver, 2008); melalui peta konsep (Daniel, Let.all, 2007); penilaian formatif (Andrew Falk, 2012); melalui metode kursus (Chatree Faikhamta, et.all 2009); melalui role palying (Marissa Rollnic, 2016); melalui lokakarya pengembangan professional (Eylem Budak\& Fitnat Köseo lu Gazi); melalui lesson study (John Lou S. Lucenario, et.all, 2016); 
(Martin Vogt Juhler, 2016); melalui explicitreflective approach (Sarah J. Krajewski \& Renee Schwartz, 2014); melalui model pengajaran berbasis web (Mehmet Barıs Horzum \& Ozlem Canan Gungoren, 2012); (Erkan Yeşiltaş, 2016); melalui pelatihan menggabungkan INTASC I and NSTA core content standards (2006); menganalisis PCK mengunakan instrumen (Sharifah Intan,et.all 2010); (Lilia Halim,et.all 2012); (Zeki Aksu, et.all 2014); melalui kegiatan mentoring (Ken Appleton, 2008); menggunakan model dan bahasa (Martina Strübe, et.all 2014) dan sebagainya. Berdasarkan analisis jurnal yang telah dilakukan, minim sekali penelitian tentang pengembangan PCK yang berkaitan dengan pendidikan karakter. Bahkan menurut (David Cross \& Celine Lepareur, 2015) sangat sedikit penelitian PCK yang berkaitan dengan pembelajaran siswa.

Pendidikan karakter bukan sesuatu yang baru, tetapi setua pendidikan itu sendiri karena sejak jaman Plato sudah dibicarakan. Walaupun 40 tahun terakhir dunia membicarakan tentang pentingnya pendidikan karakter di tengah-tengah kemorosotan nilai-nilai moral masyarakat (William G. Thompson, 2002). Seluruh warga dunia merasakan pentingnya pendidikan karakter akibat meningkatnya perilaku yang kurang baik seperti perilaku agresif dan anti sosial, penyalahgunaan narkotika dan obat-obatan, aktifitas seksual pranikah, aktifitas kriminal, rendahnya prestasi akademik dan pengabaian sekolah (Victor Battistich, 2011). Pendidikan karakter bukan hanya sekedar mengajarkan mana yang benar dan mana yang salah. Lebih dari itu, pendidikan karakter adalah usaha menanamkan kebiasaan-kebiasaan yang baik (habituation) sehingga peserta didik mampu bersikap dan bertindak berdasarkan nilai-nilai yang telah menjadi kepribadiannya. Dengan kata lain, pendidikan karakter yang baik harus melibatkan pengetahuan yang baik (moral knowing), perasaan yang baik atau loving good (moral feeling) dan perilaku yang baik (moral action) sehingga terbentuk perwujudan kesatuan perilaku dan sikap hidup peserta didik (Pusat Kurikulum, 2009). Berdasarkan hal ini, dapat dimengerti mengapa penelitian PCK yang berkaitan dengan pendidikan karakter sangat minim dilakukan. PCK membicarakan bagaimana kemampuan guru dalam meramu materi ajar agar mudaj dimengerti oleh siswa, sedangkan pendidikan karakter mengupayakan bagaimana pendidikan membentuk karakter siswa. Jadi PCK bicara tentang guru, pendidikan karakter bicara tentang siswa. Walaupun demikian, untuk memperkaya pengetahuan tentang PCK peneliti melakukan penelitian yang berjudul Analisis Pedagogogical Content Knowledge di dalam Konteks Pendidikan Karakter : Sebuah Studi Meta Analisis. Pertanyaan penelitian untuk studi ini adalah a. Bagaimanakah karakteristik umum studi PCK di dalam konteks pendidikan karakter? (seperti partisipan, instrument pengumpul data, desain penelitian, subyek dan topic studi, konteks,dan lain-lain), b. Bagaimanakah implikasi studi PCK di dalam konteks pendidikan karakter?

\section{METODOLOGI PENELITIAN}

Studi penelitian yang digunakan adalah desains studi kualitatif. Review literature menggunakan data base ERIC dengan menggunakan kata kunci pedagogical content knowledge.pdf dan google dengan kata kunci pedagogical content knowledge.pdf dan character education.pdf. Jurnal yang diperoleh disortir dan diambil jurnal PCK yang berkaitan dengan sains dan pendidikan karakter atau hasil belajar.Dari 200 jurnal PCK sains, akhirnya diambil 15 jurnal yang berkaitan langsung maupun tidak langsung dengan pendidikan karakter untuk dianalisis lebih lanjut.

\section{HASIL DAN PEMBAHASAN}

Hasil akan disajikan dalam tiga bahasan utama, yaitu yang pertama, investigasi studi dalam hal karakteristik umum studi PCK di dalam konteks pendidikan karakter; yang kedua informasi tentang bagaimana PCK diselidiki; yang ketiga analisis kaitan PCK dengan pendidikan karakter.

\section{Investigasi Instrumen Pengumpulan Data:}

Sebagian besar penelitian menggunakan beberapa instrumen pengumpulan data untuk mengungkapkan PCK peserta. Lima dari penelitian ini menggunakan wawancara, observasi dan rencana pelajaran sebagai instrument. Sebanyak 10 dari penelitian ini menggunakan kombinasi Antara wawancara, observasi, rencana pelajaran, angket dan tes.

Temuan lain yang terkait dengan instrumen adalah instrumen pengumpulan data yang paling disukai yang digunakan dalam penelitian adalah wawancara (10 penelitian).

\section{Konteks Studi}


Tidak ada konteks khusus yang digunakan dalam sebagian besar penelitian yang berkaitan dengan PCK. Namun, lima dari studi tersebut dilakukan dalam konteks kursus praktik mengajar dan ada satu studi untuk setiap metode pengajaran saja, kursus pedagogi pilihan dan program pelatihan in-service.

\section{Investigasi studi dalam hal desain}

Sebagian besar (8 jurnal) studi lebih memilih pendekatan kualitatif dan studi kasus sebagai rancangan yang paling disukai di antara pendekatan kualitatif. Desain quasi eksperimen digunakan dalam tiga penelitian, hal ini berarti pendekatan kuantitatif digunakan. Mixed method digunakan oleh tiga penelitian sedangkan satu penelitian menggunakan action research. Informasi tentang bagaimana Komponen PCK diselidiki adalah hanya satu komponen PCK yang dipelajari dalam tiga penelitian, sedangkan enam penelitian meneliti lebih dari satu komponen PCK. Namun, tidak ada penelitian yang meneliti semua komponen PCK. Pengetahuan tentang peserta didik, kurikulum dan strategi instruksional ada di antara komponen PCK yang banyak dipelajari. Enam studi penelitian mempelajari PCK secara umum tanpa memusatkan perhatian pada komponen PCK manapun.

\section{Investigasi hubungan antara komponen PCK}

Tidak ada peneltian yang mencari hubungan antar komponen PCK. Studi yang menyelidiki perkembangan PCK: hanya tujuh studi yang meneliti pengembangan PCK peserta dalam jangka waktu tertentu seperti satu semester sedangkan delapan penelitian tidak bertujuan untuk menguji pengembangan PCK. Studi Membandingkan PCK sebanyak tujuah penelitian. Misalnya, satu studi melibatkan perbandingan PCK guru yang bekerja di sekolah negeri dan sekolah swasta.

\section{Investigasi yang berkaitan Antara PCK dengan pendidikan karakter}

Penelitian PCK yang menyangkut pendidikan karakter secara khusus hampir tidak ditemukan. Namun demikian ada beberapa penelitian PCK yang mengaitkan dengan hasil belajar berupa karakter tertentu. Karakter yang ditelaah diantaranya adalah karakter kreatif dan rasa ingin tahu (satu jurnal); karakter confidence \& meaning fullness; affective, perceived control, cognitive belief teacher, efficacy state; sikap guru; social responsibility \& self actualization; solving skill.

\section{Temuan}

Temuan yang diperoleh dari investigasi studi PCK yang berkaitan dengan pendidikan karakter adalah :

a. PCK guru menjadi syarat perlu, namun tidak menjadi syarat cukup untuk meningkatkan karakter peserta didik [54]. Karakter kreatif peserta didik dari guru pada kelompok Maturing PCK maupun Growing PCK pada tingkatan sedang dan rendah. Karakter rasa ingin tahu peserta didik dari guru pada kelompok Maturing PCK pada tingkatan tinggi, sedang dan rendah. Karakter rasa ingin tahu peserta didik dari guru pada kelompok Growing PCK pada tingkatan sedang dan rendah.

b. Tidak ada hubungan yang signifikan antara CK dan PCK. Analisis lebih lanjut menunjukkan bahwa PCK diperoleh setelah pelatihan pengajaran penyelidikan ilmiah memprediksi sikap selanjutnya. Sebelum CK tidak mempengaruhi sikap selanjutnya mengenai pengajaran penyelidikan ilmiah. Selain itu, sikap sebelumnya tidak secara substansial memprediksi PCK dan CK berikutnya. Selain itu, pengalaman mengajar sebelumnya dalam biologi menjelaskan perbedaan individu, dan sikap self-efficacy memprediksi perubahan sikap sehubungan dengan pengajaran penyelidikan ilmiah pada akhir pelatihan. Kesimpulan: Tampaknya seminar pelatihan PCK yang singkat pun dapat mempengaruhi sikap guru pra-layanan terhadap penyelidikan ilmiah. Makanya, program pendidikan mengajar harus dirancang untuk memperluas PCK (Robbert Smit, et.all 2017).

c. PCK dapat mempengaruhi tindakan siswa dalam hal ini minat/motivasi dan prestasi (David Cross \& Celine Lepareur, 2015).

d. PCKLS (Pedagogical Content Knowledge Lesson Study) meningkatkan solving skill dan konsepsi siswa (John LouS. Lucenario, et.all).

e. PCK dikembangkan melalui tindakan refleksi dan refleksi berdasarkan konteks instruksional. Keampuhan guru muncul sebagai afiliasi afektif PCK. Siswa memiliki dampak penting pada perkembangan PCK. Kesalahpahaman siswa memainkan peran penting dalam membentuk PCK, dan PCK sangat istimewa dalam beberapa aspek dari pemberlakuannya (Soonhye Park \& J. Steve Oliver, 2008). 
Quagga: Jurnal Pendidikan dan Biologi

Volume 11, Nomor 1, Januari 2019

f. Prestasi sains siswa meningkat dengan kurikulum PBS, namun sikap mereka terhadap sains dan rencana untuk mengejar sains tidak. Peningkatan pada guru CK dan PCK dengan pengembangan profesional berkorelasi dengan peningkatan prestasi belajar siswa namun tidak berkorelasi dengan perbaikan sikap atau rencana sains siswa. Namun, frekuensi guru menggunakan aktivitas berbasis penyelidikan khusus berkorelasi dengan perbaikan pada sikap dan rencana sains siswa. Insum, sejauh mana keberhasilan kurikulum PBS dengan siswa dari kelompok-kelompok yang direpresentasikan dalam karir science nampaknya bergantung pada unsur-unsur pengetahuan guru (CK dan PCK) dan frekuensi guru dalam penggunaan aktivitas berbasis penyelidikan yang sesuai dengan budaya yang relevan (Davide.Kanter \& Spyros Konstantopoulus, 2010).

\section{SIMPULAN DAN SARAN}

Setelah meninjau studi tentang PCK yang berkaitan dengan pendidikan karakter, ditemukan sangat sedikit penelitian yang menyangkut hal tersebut. Hal ini bisa dimaklumi karena konsentrasi penelitian PCK adalah bagaimana mengembangkan kemampuan professional guru, sedangkan pendidikan karakter adalah salah satu hasil belajar siswa. Sehubungan dengan hal tersebut, penelitian tentang PCK yang berkaitan dengan pendidikan karakter merupakan celah untuk terus diteliti. Secara umum, penelitian PCK biasanya mengeksplorasi PCK guru preservice atau calon guru, sedikit sekali penelitian dilakukan pada guru in-service. Hal ini merupakan kebalikan pada penelitian yang berkaitan dengan pendidikan karakter yang lebih banyak mengeksplorasi PCK guru in-service.

Penelitian PCK umumnya menggunakan instrument wawancara sebagai instrumen yang sering digunakan. Hal ini wajar karena umumnya penelitian PCK menggunakan pendekatan kualitatif yang memerlukan wawancara sebagai instrument untuk menggali informasi lebih dalam.

\section{Saran}

a. Program, lokakarya dan program pelatihan in-service untuk meningkatkan PCK guru pre-dan in-service akan bermanfaat bagi pengembangan PCK

b. Staf pengajar di universitas harus menggunakan metode pengajaran yang
p-ISSN 1907-3089, e-ISSN 2651-5869

https://journal.uniku.ac.id/index.php/quagga

berbeda dalam kursus konten dan pedagogi dalam program pendidikan guru.

c. Mentor berpengalaman yang akan menjadi panutan bagi guru pra-layanan dalam hal menggunakan strategi pembelajaran dan komponen PCK lainnya secara efektif harus dipilih untuk kursus praktik mengajar.

d. Isi kursus dalam program pendidikan guru penting. Kursus metode pengajaran penting karena guru pra-layanan memiliki kesempatan untuk belajar tentang metode pengajaran yang berbeda.

e. Perlu dikembangkan PCK yang berkaitan dengan pendidikan karakter dan dilatihkan sejak mereka mahasiswa calon guru.

\section{REFERENSI}

Abd-el-Khalick, F. 2006. "Preservice and experienced biology teachers' global andspecific subject matter structures: Implications for conceptions of pedagogical content knowledge". Eurasia Journal of Mathematics, Science and Technology Education, 2,(1), 1-29.

Adam Bertram \& John Loughran. 2012. Science Teachers' Views on CoRes and PaP-eRs as a Framework for Articulating and Developing Pedagogical Content Knowledge. Res Sci Educ. 42:1027-1047.

Andrew Falk. 2012. Teachers Learning From Professional Development in Elementary Science: Reciprocal Relations Between Formative Assessment and Pedagogical Content Knowledge. Science Education, Vol. 96, No. 2, pp. 265-290

Anne Hume. 2010. CoRes asTools for Promoting Pedagogical Content Knowledge of Novice Science Teachers. ChemEd, 119, 13-19

Betu"1 Demirdo“g־en. 2016. Interaction Between Science Teaching Orientation and Pedagogical Content Knowledge Components. J Sci Teacher Educ. 27:495-532

Blömeke, S. \& Delaney, S. 2012. Assessment of teacher knowledge across countries: A review of the state of research. ZDM Mathematics Education, 44, 223-247

Byoung S. Kim. Eun K. Ko, Norman G. Lederman \& Norman G. Lederman. A Developmental Continuum of Pedagogical Content Knowledge for Nature of Science Instruction. (online). Tersedia : 
Quagga: Jurnal Pendidikan dan Biologi

Volume 11, Nomor 1, Januari 2019

https://www.researchgate.net/.../22895449

5. (Diunduh tanggal 9 Nopember 2017)

Chatree Faikhamta, Richard K. Coll \& Vantipa Roadrangka. 2009. The Development of Thai Pre-service Chemistry Teachers' Pedagogical Content Knowledge: From a Methods Course to Field Experience. Journal of Science and Mathematics The Development of Thai Pre-service Chemistry Education in Southeast Asia, Vol. 32 No. 1, 18-35

Claire H. Majori \& Betsy Palmer. 2006. Reshaping teaching and learning: The transformation of faculty pedagogical content knowledge. Higher Education. 51: 619-647

Clara Alvarado, Florentina Cañada, Andoni Garritzc \& Vicente Melladob. 2015. Canonical pedagogical content knowledge by CoRes for teaching acid-base chemistry at high school. Chemistry Education Research and Practice. 16, pp. 603-618 DOI: 10.1039/c4rp00125g.

Daniel L. Dickerson, Karen R. Dawkins \& Len Annetta. 2007. Scientific Fieldwork: An Opportunity for Pedagogical-Content Knowledge Development. Journal of Geoscience Education, v. 55, n. 5, November, p. 371-376

David Cross \& Celine Lepareur. 2015. PCK at Stake in Teacher-Student Interaction in Relation to Students' Difficulties. Sense Publishers, P.O. Box 21858, 3001 AW Rotterdam, The Netherlands

Davide.Kanter \& Spyros Konstantopoulus. 2010. The Impact of a Project-Based Science Curriculum on Minority Student Achievement, Attitudes, and Careers: The Effects of Teacher Contentand Pedagogical Content Knowledge and Inquiry-Based Practices. Science Eduation Sci Ed94 : 855-887.

Dilek Karışan. 2013. A science Teacher's PCK in Classes with Different Academic Success Levels. Journal of Educational and Instructional Studies in the World. Vol. 3.04. 22-31.

Erkan Yeşiltaş. 2016. An Analysis of Social Studies Teachers' Perception Levels Regarding Web Pedagogical Content Knowledge. International Education Studies; Vol. 9, No. 4;pp. 108-123

Erni Widiyastuti. 2016. Analisis Pedagogical Content Knowledge Guru, Literasi
p-ISSN 1907-3089, e-ISSN 2651-5869

https://journal.uniku.ac.id/index.php/quagga

Matematika, dan Karakter Peserta Didik. Thesis. Universitas Negeri Semarang

Eylem Budak, Fitnat Köseo lu Gazi. What Concept Maps Tell us about Changes in Pedagogical Content Knowledge of Prospective Chemistry Teachers Participating in an Inquiry Based Workshop?. (online). Tersedia: http://cmc.ihmc.us/cmc2008papers/cmc20 08-p280.pdf. (Diunduh tanggal 9 Nopember 2017)

Federick J. Ngo. 2013. The distribution of pedagogical content knowledge in Cambodia: Gaps and thresholds in math achievement. Educ Res Policy Prac. 12:81-100

Heater C Hill. 2008. Unpacking Pedagogical Comtent Knowledge :Conceptualizing and measuring Teacher's Topic Specific Knowledge of Student. Journal For Reserch in Mathematic Education. Vol. 39. 4. 372-400

Jan H. van Driel, Nico Verloop, \& Wobbe de Vos. 1998. Developing Science Teachers' Pedagogical Content Knowledge. Journal of research in science teaching Vol. 35, No. 6, pp. 673-695

John Lou S. Lucenario, Rosanelia T. Yangco, Amelia E. Punzalan, \& Allen A. Espinosa. 2016. Pedagogical Content KnowledgeGuided Lesson Study: Effects on Teacher Competence and Students' Achievement in Chemistry. Education Research International Volume 2016, Article ID 6068930, 9 pages. https://www.hindawi.com/journals/edri/20 16/6068930/(Diunduh tanggal 9 Nopember 2017)

John LouS. Lucenario, RosaneliaT.Yangco, AmeliaE.Punzalan,

andAllenA.Espinosa.Pedagogical Content Knowledge-Guided Lesson Study: Effects on Teacher Competence and Students' Achievement in Chemistry. Education Research International.1-9.

John Williams \& John Lockley. 2012. Using CoRes to Develop the Pedagogical Content Knowledge (PCK) of Early Career Science and Technology Teachers. Journal of Technology Education Vol. 24 No. 1, Fall.pp. 34-53

Ken Appleton. 2008. Developing Science Pedagogical Content Knowledge Through 
Quagga: Jurnal Pendidikan dan Biologi

Volume 11, Nomor 1, Januari 2019

Mentoring Elementary Teachers. J Sci Teacher Educ 19:523-545

Kim Lange, Thilo Kleickmann \& Kornelia Möller. 2012. Elementary Teachers' Pedagogical Content Knowledge and Student Acievement in Science Education. Science Learning and Citizenship.

Lee S. Shulman. 1986.Those Who Understand: Knowledge Growth in Teaching. Educational Researcher, Vol. 15, No. 2 . pp. 4-14

Lilia Halim, T. Subahan Mohd Meerah, Effandi Zakaria, Sharifah Intan Sharina Syed Abdullah \& Tarzimah Tambychik. 2012. An Exploratory Factor Analysis in Developing Pedagogical Content Knowledge Scale for Teaching Science. Research Journal of Applied Sciences, Engineering and Technology 4(19): 35583564

Loughran, John., Berry, Amanda., \& Mulhall, P. 2012. Understanding and Developing Science Teachers' Pedagogical Content Knowledge. Ed. 2. Rotterdam/Taipei: Sense Publishers. Pp.211-231.

Magnusson, S., Krajcik, J. \& Borko, H. 1999. Nature, sources, and development of pedagogical content knowledge for science teaching. In J. Gess-Newsome \& N. G. Lederman (Eds.). Examining pedagogical content knowledge: The construct and its implications for science education (pp.95-132). Dordrecht, the Netherlands, Kluwer

Marissa Rollnic. 2016. Learning About Semi Conductors for Teaching-the Role Played by Content Knowledge in Pedagogical Content Knowledge (PCK) Development. Res Sci Educ. Vol. 47 (4).pp. 833-868

Martin Vogt Juhler. 2016. The Use of Lesson Study Combined with Content Representation in the Planning of Physics Lessons During Field Practice to Develop Pedagogical Content Knowledge. J Sci Teacher Educ DOI 10.1007/s10972-01694734https://link.springer.com/article/10. 1007/s10972-016-9473-4(Diunduh tanggal 9 Nopember 2017)

Martina Strübe, Holger Tröger, Oliver Tepner, \& Elke Sumfleth. 2014. Development of a Pedagogical Content Knowledge test of chemistry language and models. Educ. quím., 25(3), 380-390
p-ISSN 1907-3089, e-ISSN 2651-5869

https://journal.uniku.ac.id/index.php/quagga

Mehmet Baris Horzum \& Ozlem Canan Gungoren. 2012. A Model for Belief, Tool Acceptance Levels and Web Pedagogical Content Knowledge of Science and Technology Preservice Teachers Towards Web Based Instruction. Turkish Online Journal of Distance Education-TOJDE ISSN 1302-6488 Volume: 13 Number: 3 Article 3. Pp.50-69

Miranda. 2008. Pedagogical Content Knowledge and Enginering and Technology Teacher Education: Issues for thought. Journal of the Japanese Society of Thechnology Education 50 (1) 17-26

Morine-dershimer, G., \& Kent, t. (1999). the complex nature and sources of teachers' pedagogical knowledge. in: Gessnewsome, J.; lederman, n.G. (eds.) Examining Pedagogical Content Knowledge, dordrecht, the netherlands: Kluwer academic publishers, p. 21-50.

Mulholland, J., \& Wallace, J. 2005. "Growing the tree of teacher knowledge: Ten years of learning to teach elementary science". Journal of Research in Science Teaching, 42, 767-790

Mustafa ÖZDEN. 2008. The Effect of Content Knowledge on Pedagogical Content Knowledge: The Case of Teaching Phases of Matters. Educational Sciences: Theory \& Practice 8 (2). 633-645

NSTA \& AETS .1998.. Standard for Science Tiecher Preparation

Nurcan CANSIZ \& Mustafa CANSIZ. 2016. Preservice Science Teachers' Orientations Towards Teaching Science to Middle Schoolers. International Journal on New Trends in Education and Their Implications. Volume: 7 Issue: 3 Article: 08.pp.69-78

OECD. Teachers' Pedagogical Knowledge and the Teaching Profession. Pp. 1-7. http://www.oecd.org/edu/ceri/Background document to Symposium ITELFINAL.pdf. (diunduh 31 Oktober 2017)

Pernilla Nilsson \& John Loughran. 2012. Exploring the Development of Pre-Service Science Elementary Teachers' Pedagogical Content Knowledge. J Sci Teacher Educ. 23:699-721

Prasart Nuangchalerm. 2012. Enhancing Pedagogical Content Knowledge in Preservice Science Teachers. Higher Education Studies Vol. 2, No. 2.pp. 66-71 
Quagga: Jurnal Pendidikan dan Biologi

Volume 11, Nomor 1, Januari 2019

Pusat Kurikulum. Pengembangan dan Pendidikan Budaya dan Karakter Bangsa: Pedoman Sekolah. 2009:9-10

Raimundo Olfos, Tatiana Goldrine \& Soledad Eetrella. 2014. Teachers' pedagogical content knowledge and its relation with students' understanding. Revista Brasileira de Educação v. 19 n. 59 out.dez.

Robbert Smit , Holger Weitzel, Robert Blank, Florian Rietz, Josiane Tardent \& Nicolas Robin. 2017: Interplay of secondary preservice teacher content knowledge (CK), pedagogical content knowledge (PCK) and attitudes regarding scientific inquiry teaching within teacher training, Research in Science \& Technological Education, DOI: 10.1080/02635143.2017.1353962

Sarah J. Krajewski \& Renee Schwartz. 2014. A Community College Instructor's Reflective Journey Toward Developing Pedagogical Content Knowledge for Nature of Science in a Non-majors Undergraduate Biology Course. J Sci Educ Technol (2014) 23:227-237

Sevgi AYDIN \& Yezdan BOZ. 2012. Review of Studies Related to Pedagogical Content Knowledge in the Context of Science Teacher Education: Turkish Case. Educational Sciences: Theory \& Practice 12(1) Winter 497-505.

Sharifah Intan, Sharina Syed Abdullaha \& Lilia Halim. 2010. Development of instrument measuring the level of teachers' Pedagogical Content Knowledge (PCK) in environmental education. Procedia Social and Behavioral Sciences 9. 174-178

Soonhye Park \& J. Steve Oliver. 2008. Revisiting the Conceptualisation of Pedagogical Content Knowledge (PCK): PCK as a Conceptual Tool to Understand Teachers as Professionals. Res Sci Educ. 38:261-284

Sri Sukaesih, Saiful Ridlo, \& Sigit Saptono. 2017. Profil Kemampuan Pedagogical Content Knowledge (PCK) Calon Guru Biologi. Lembaran Ilmu Kependidikan. Volume 46. Nomor 1. Pp. 68-74

Stephan Schmelzing, Jan H. Driel, Melalnie Juttner, Stefanie Brandenbusch, Angela
p-ISSN 1907-3089, e-ISSN 2651-5869

https://journal.uniku.ac.id/index.php/quagga

Sandmann \& Birgit J. Neuhaus. 2013. Development, Evaluation, and Validation of A Peper-and-Pencil Test for Measuring Two Component of Biology Teacher's Pedagogical Content Knowledge Concerning the 'Cardiovascular System. International Journal of Science and Mathematics Education. 11: 1369Y1390

The Association for Science Education, Institute of Physics, Royal Society of Biology, Royal Society of Chemistry and the Royal Society. 2015. Teachers' professional development standard. Pp. 1-23

Thilo Kleickmann, Dirk Richter, Mareike Kunter, Jürgen Elsner, Michael Besser, Stefan Krauss, and Jürgen Baumert. 2013. Teachers' Content Knowledge and Pedagogical Content Knowledge: The Role of Structural Differences in Teacher Education. Journal of Teacher Education 64(1) 90-106

Victor Battistich. 2011. Character Education, Prevention, and Positive Youth Development.[Online]. Tersedia: http://www.character.org/wpcontent/uploads/2011/12/white_paper_bat tisch.pdf.

William G. Thompson. 2002. The Effects of Character Education on Student Behavior.[Disertasi]. East Tennessee State University.

Yeni Rahmadhani, Adi Rahmat, \& Widi Purwianingsih. 2016. Pedagogical Content Knowledge (PCK) Guru dalam Pembelajaran Biologi SMA di Kota Cimahi. Prosiding Seminar Nasional Sains dan Pendidikan Sains. 6:17-24

Zeki Aksu, Mustafa Metin \& Alper Cihan KonyalÖoølu. 2014. Development of the Pedagogical Content Knowledge Scale for Pre-Service Teachers: The Validity and Reliability Study. Mediterranean Journal of Social Sciences MCSER Publishing, Rome-Italy Vol 5 No 20.pp.1365-1377 